\title{
The ocelot Leopardus pardalis in north-western Mexico: ecology, distribution and conservation status
}

\author{
Carlos A. López González, David E.Brown and Juan P. Gallo-Reynoso
}

\begin{abstract}
From July 1998 to July 2000 we collected locality information and habitat associations for 36 records of the Endangered ocelot Leopardus pardalis in the Mexican State of Sonora. Twenty-seven (75\%) of the records for which we could determine the biotic community association were associated with tropical and subtropical habitats, namely subtropical thornscrub, tropical deciduous forest or tropical thornscrub. Only males $(11.1 \%$ of the total records) have been recorded in temperate oak and pine-oak woodland, and we conclude that the few ocelots reported from these habitats in the US State of Arizona were probably dispersing
\end{abstract}

individuals. Three models of ocelot distribution in Sonora, based on vegetation types, the GARP modelling system and the Adaptive Kernel home range estimator, all produced similar results, with the ocelot mostly associated with the mountainous Sierra region of eastern Sonora. Large tracts of land with a low human population density make Sonora a stronghold for the northernmost distribution of ocelots.

Keywords Arizona, bobcat, habitat association, Leopardus pardalis, Lynx rufus, Mexico, ocelot, Sonora.

\section{Introduction}

The ocelot Leopardus pardalis (Carnivora, Felidae) is considered to be in danger of extinction in the United States and Mexico (Favre, 1989; SEDESOL, 1994; USFWS, 1999). The US Endangered Species Act categorizes the ocelot as Endangered throughout its range (Arizona, Texas, Mexico, Central \& South America; Endangered Species Program, 2003), whereas the IUCN Red List (IUCN, 2002) only categorizes the Texas subspecies L. pardalis albescens as Endangered (based on criteria D, i.e. population estimated to be $<250$ mature individuals). The most important causes of the decline of this species have been identified as poaching, over-harvesting when it was legal to hunt them, and habitat transformation (Nowell \& Jackson, 1996). Historically the ocelot ranged from Arizona to Argentina, and has been associated with a wide range of habitats, including mangrove forests, savannah grasslands, thornscrub and tropical forests of all types. Ocelots typically occur at elevations below 1,200 m (Nowell \& Jackson, 1996), and their presence is

Carlos A. López González (Corresponding author) Denver Zoological Foundation and Northern Rockies Conservation Cooperative, 2300 Steele St, Denver C0 80205-4899, USA. E-mail: Cats4mex@aol.com

David E. Brown Department of Biology, Arizona State University, P.O. Box 871501, Tempe AZ 85287-1501, USA.

Juan P. Gallo-Reynoso Centro de Investigación en Alimentación y Desarrollo, A.C. Unidad Guaymas, Carretera a Varadero Nacional Km 6, Apdo Postal 284, Guaymas, Sonora 85480, México.

Received 25 October 2000. Revision requested 25 April 2001 Accepted 6 March 2003. linked to thick vegetation cover (Tewes, 1986; Oliveira, 1994; Murray \& Gardner, 1997).

The subspecies Leopardus pardalis sonoriensis in the Mexican state of Sonora was described by Goldman (1943) on the basis of four specimens, three male and one female, obtained near Camoa in southernmost Sonora. Records of ocelots from the Mexican state of Sonora are scarce (Leopold, 1959). In former times ocelots probably ranged along the western slopes of the mountains of eastern Sonora (Caire, 1997). Burt (1938) procured a specimen from near Guirocoba that was found in tropical deciduous forest near the town of Alamos. However, despite the lack of museum specimens, ocelots are known to occur in central and northern Sonora. The Lee brothers killed an ocelot in 1935 in subtropical thornscrub near the junctions of the Aros, Bavispe and Yaqui rivers (McCurdy, 1981). A hunter killed a male in c. 1966 in oak woodland in the Sierra Azul in northern Sonora (Sewell Goodwin, pers. comm.), and another ocelot was killed in this same area in 1974 (Bill Robinson, pers. comm.).

Ocelots documented from the south-western United States are one hide sent to the US National Museum from Fort Verde, Arizona, by E.A. Mearns in 1887, a skull from an archeological site on the San Pedro River near Redington (Burt, 1961), one reportedly killed by a US Biological Survey predator control agent during 1931-1932 (Brown, 1989), a male killed and photographed in 1964 on Pat Scott Peak in the Huachuca Mountains (Brown, 1985; Sewell Goodwin, pers. comm.), and a male that had been run over near the town of Oracle in 1967 (Jack Childs, pers. comm.). 
The state of Sonora is the second largest state in Mexico, and has one of the lowest human population densities in the country. Relatively intact patches of continuous habitat therefore make this area a stronghold for rare species such as the jaguar Panthera onca and river otters Lontra longicaudis (López González \& Brown, 2002; Gallo, 1996), and potentially also for the ocelot. In this paper we address the paucity of information on the distribution, habitat associations and conservation status of the ocelot in Sonora by drawing together both historical and recent information on the species. We use this data to model the species' distribution in Sonora, and to discuss the potential for colonization by the ocelot of the south-western United States.

\section{Methods}

We began obtaining ocelot records from the Mexican State of Sonora during a state-wide jaguar survey (López González \& Brown, 2002); additional records were collected opportunistically by JPGR. The state of Sonora is situated in north-western Mexico, immediately to the south of the US state of Arizona (Fig. 1), and

Fig. 1 (a) The State of Sonora in north-western Mexico; the rectangle indicates the location of Figs b-d. (b) Vegetation types where most of the ocelot records were located. (c) GARP model predicting the distribution of ocelots. (d) Adaptive Kernel model for ocelot distribution, with the $95 \%$ probability contour. (Figs b-d, see text for details.)

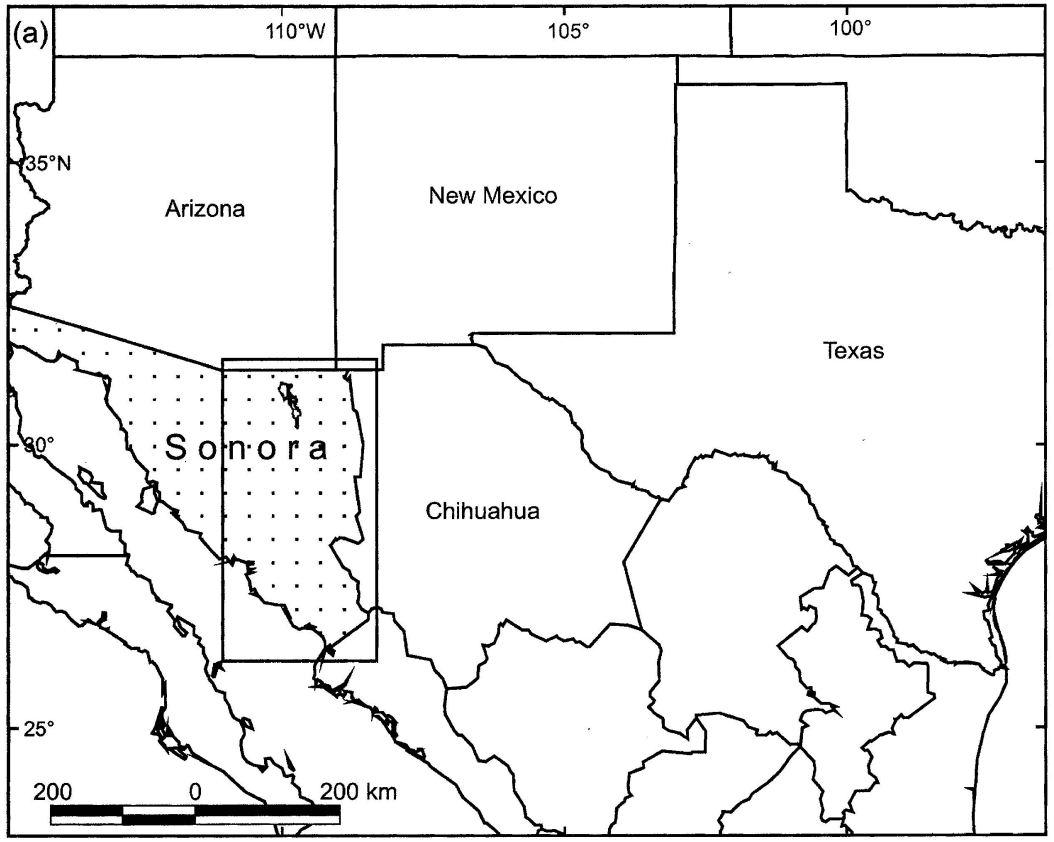

(b) Vegetation types

(c) GARP model

(d) Adaptive kernel

55 Subtropical thornscrub

C/2 Tropical deciduous forest
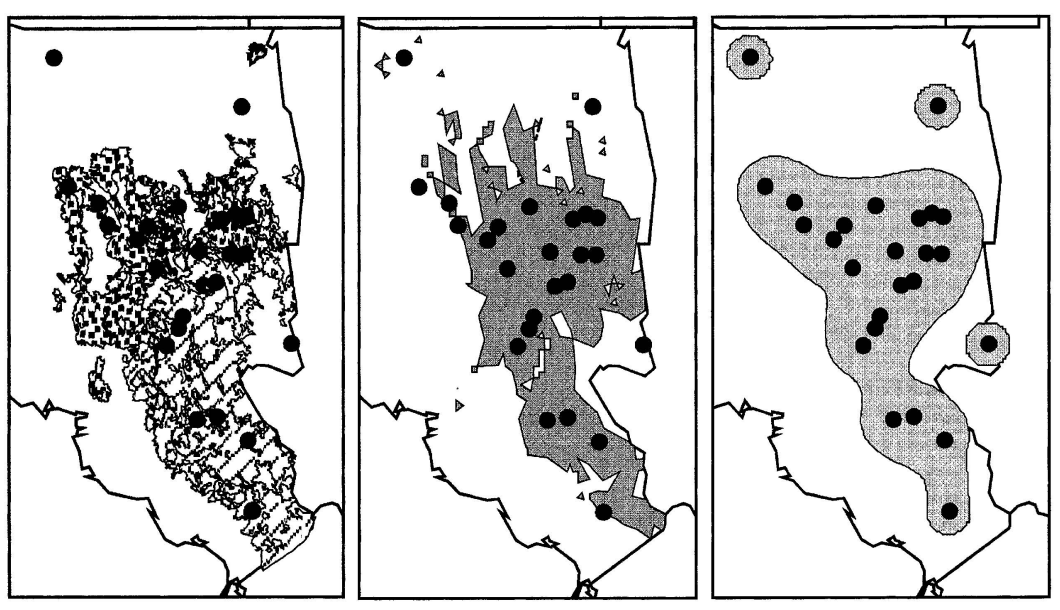
encompasses $c .182,000 \mathrm{~km}^{2}$. It is a complex mosaic of temperate and tropical biotic communities, and includes the northernmost limits of the neotropics (Brown et al., 1998; Reichenbacher et al., 1998). We used the vegetation and land use categories defined by the Mexican National Commission for Knowledge and Use of Biodiversity (CONABIO, 1999), which recognizes the following biotic communities in the state of Sonora: agricultural lands, low open forest, oak woodland, oak-pine woodland, gallery forest, pine forest, pine-oak forest, juniper forest, chaparral, mangrove forest, desert thornscrub, subtropical thornscrub, mesquite forest, grasslands, tropical deciduous forest, tropical thorn forest, halophile vegetation, sand desert, sand dunes, and others (urban areas, lakes, no apparent vegetation).

The state is divided into 72 municipalities. We visited all of these and asked ranchers, cowboys, cattle associations and outfitters if they knew of any ocelots killed in the area. We attempted to corroborate all ocelot reports by locating photographs, skins, skulls and other evidence. When possible these materials were photographed and catalogued as to owner, sex, age, and location. Verified records are those for which we were able to unambiguously document an individual ocelot and observe the locality of capture. These were located on 1:250,000 topographical maps (INEGI, 1973) and then plotted on a digitized vegetation and land use map (scale 1:250,000; CONABIO, 1999), and the approximate elevation was recorded. Notes were also taken on the habitat affiliation of each record, and the human density and land-use of the area.

We constructed three distribution models: one based on broad vegetation types present in the state of Sonora, a second using ecological niche models using the Genetic Algorithm for Rule-Set Production (GARP) modelling system (Stockwell \& Noble, 1991; Stockwell \& Peters, 1999), and a third one using the Adaptive Kernel home range estimator (Worton, 1989). GARP identifies correlations between a species distribution and environmental characteristics through an iterative process of rule selection, evaluation, testing, and incorporation or rejection. A rule is a pattern in the environment, and has the basic form: "if something is true then something necessarily follows". The "if" part of the rule is the precondition, and the "then" part the conclusion; the preconditions of rules in GARP are simple conjunctive expressions. A rule set is an unordered list of rules (Stockwell \& Noble, 1991; Stockwell \& Peters, 1999). The GARP algorithm runs for 10,000 iterations, or until rule testing has no appreciable effect on the accuracy measure. Complete details and documentation are available elsewhere (Stockwell \& Noble, 1991; Stockwell \& Peters, 1999; DesktopGarp, 2003). Geographic themes consisted of four coverages provided by CONABIO
(1999): elevation (500 m intervals), mean annual precipitation (10 categories), annual mean temperature (5 categories), and vegetation (Rzedowski, 1979). Because GARP generates distributional predictions based on random rule selection, and predictions vary somewhat from one run to the next, we generated six GARP models, each having 10,000 simulations. To obtain a single representative prediction the six were overlain, and only retained pixels for which all models predicted ocelot presence.

The Adaptive Kernel method is a home range estimator that can be used to calculate the area used by a population. This method was used by Lopez Gonzalez (1999) to delineate reserve sizes for pumas Puma concolor, and by Bader (2000) to estimate the distribution of grizzly bear Ursus ursus. The method uses probability to construct a distribution using the individual location records. For the present study we constructed a distribution based on the $95 \%$ probability contour.

\section{Results}

We obtained a total of 36 verified ocelot records for Sonora (Table 1, Fig. 1), 35 of which were records of single individuals and one of four individuals; 29 of the records were from our surveys and seven from the literature and personal communications. Five of the records lacked information on date killed and/or locality, and of the remaining, 21 were killed after and 10 before 1990. The approximate range of ocelots in Sonora as defined by our records and estimated through available vegetation types was $39,093 \mathrm{~km}^{2}$ (Fig. 1b). The estimate of ocelot range using the GARP model covers an area of $35,525 \mathrm{~km}^{2}$ (Fig. 1c), and that using the Adaptive Kernel home range estimator (Worton, 1989) was $44,459 \mathrm{~km}^{2}$ (Fig. 1d) for a $95 \%$ probability of occurrence.

27 of the 36 records $(75 \%)$ of ocelots in Sonora were associated with tropical or subtropical habitats, namely subtropical thornscrub, tropical deciduous forest and tropical thornscrub (Table 2). The mean elevation of the 33 records located with precision was $700 \pm 450 \mathrm{~m}$, at which altitudes subtropical thornscrub is the main habitat.

Individual male records comprised $48.7 \%(n=19)$ and females $15.4 \%$ ( $n=6$, including one tentatively identified as female). We were not able to determine the sex for the remaining $35.9 \%$ of the records as they were either poorly preserved or their sex was not documented in the literature. The most northerly limit of a record of a female, typically indicative of a breeding population, was $30^{\circ} 30^{\prime}$ latitude. There was only one record of a kitten, in the southern part of the State. 
Table 1 Ocelots Leopardus pardalis known to have been killed in the Mexican State of Sonora between 1898 and 2000, in reverse chronological order.

\begin{tabular}{|c|c|c|c|c|}
\hline Year & 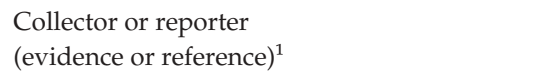 & Sex & Locality or Municipality & Biotic community \\
\hline 2000 & Cowboy (CALG saw skin; photos) & M & Rancho Tapila, Agua Prieta & Pine-oak forest \\
\hline 2000 & Cowboy (CALG saw skin) & M & Sierra Los Chinos, Sahuaripa & $\begin{array}{l}\text { Temperate Oak } \\
\text { woodland-subtropical } \\
\text { thornscrub }\end{array}$ \\
\hline 1999 & Cowboy (CALG has skin) & M & Basopa, Sahuaripa & Subtropical thornscrub \\
\hline 1999 & Rancher (photo) & M & Rancho La Placita, Sahuaripa & Subtropical thornscrub \\
\hline 1999 & Rancher (CALG saw skin) & M & Rancho Los Taraices, Aconchi & Subtropical thornscrub \\
\hline 1999 & Rancher (CALG saw skin) & $\mathrm{M}$ & Sierra de Alamos, Alamos & Tropical deciduous forest \\
\hline 1999 & Rancher (CALG saw skin) & $\begin{array}{l}\mathrm{M} \\
\text { (kitten) }\end{array}$ & $9 \mathrm{~km} \mathrm{~W}$. of Rosario de Tezopaco & Tropical deciduous forest \\
\hline 1999 & Rancher (CALG saw skin) & $\mathrm{F}$ & Rosario de Tezopaco & Tropical thornscrub \\
\hline 1997 & Houndsman (photo) & M & Sierra de los Chinos, Sahuaripa & Subtropical thornscrub \\
\hline 1995 & Houndsman & $\mathrm{F}$ & San Javier & Tropical deciduous forest \\
\hline 1995 & Houndsman (photo) & M & San Javier & Temperate Oak woodland \\
\hline 1995 & Rancher (CALG saw skin) & $\mathrm{F}$ & Rio Moctezuma, Moctezuma & Subtropical thornscrub \\
\hline 1995 & Rancher (CALG saw skin) & M & Rio Moctezuma, Moctezuma & Subtropical thornscrub \\
\hline 1995 & Rancher (JPGR has skin) & $?$ & 4 km E. of San Bernardo, Alamos & Tropical deciduous forest \\
\hline 1995 & Rancher (JPGR has skin) & $?$ & Rancho Carrizal Quemado, Granados & Subtropical thornscrub \\
\hline 1994 & Rancher (JPGR has skin) & M & Granados/Sahuaripa & Subtropical thornscrub \\
\hline 1994 & Rancher & M & Rancho San Vicente, Quiriego & $\begin{array}{l}\text { Temperate oak } \\
\text { woodland-tropical } \\
\text { deciduous forest }\end{array}$ \\
\hline 1993 & Rancher & M & Arroyo de la Junta, Ures & Subtropical thornscrub \\
\hline Before 1992 & Peter Warren, pers. comm. & $?$ & E. of Soyopa, Soyopa & Tropical deciduous forest \\
\hline Before 1992 & $\begin{array}{l}\text { Peter Warren, pers. comm. } \\
\text { (animal taken to Centro Ecologico de Sonora) }\end{array}$ & $\mathrm{F} ?$ & Tonichi & Tropical deciduous forest \\
\hline 1991 & Houndsman & $?$ & Bacanora & Desert thornscrub \\
\hline Before 1990 & Rancher & M & Rancho de los Nogales, Opodepe & Subtropical thornscrub \\
\hline 1989 & Pete Manes pers. comm. (road kill; photo) & $\mathrm{F}$ & Hwy \# 9, Rosario & Tropical deciduous forest \\
\hline 1988-1989 & Hunter (Arturo Ortega) & ? & Rancho La Montosa & Subtropical thornscrub \\
\hline 1974 & Houndsmen (Bill Robinson pers. comm.) & ? & Near Casitas, Nogales & Temperate oak woodland \\
\hline 1970 & Kelly Neal saw trapped animal & $?$ & Rancho El Valle, Arizpe & Temperate oak woodland \\
\hline 1966 & Houndsmen (Sewell Goodwin, L. Elias; photo) & M & Sierra Piñitos, E. of Casitas, Nogales & Temperate oak woodland \\
\hline Before 1965 & Houndsman (CALG saw skin) & M & Sierra de Alamos, Alamos & Tropical deciduous forest \\
\hline 1935 & Dale Lee et al. (McCurdy, 1981) & $?$ & $\begin{array}{l}\text { Junction of the Aros and Bavispe, } \\
\text { Sahuaripa rivers }\end{array}$ & Subtropical thornscrub \\
\hline Before 1938 & W.H. Burt (Burt, 1938) & $?$ & Guirocoba, S. of Alamos & Tropical deciduous forest \\
\hline 1898 & E.A. Goldman (Goldman, 1943) & $\begin{array}{l}3 \mathrm{M} \\
1 \mathrm{~F}\end{array}$ & Near Camoa, Alamos & Tropical deciduous forest \\
\hline ? & Rancher & $?$ & San Pedro de la Cueva & $\begin{array}{l}\text { Temperate Oak } \\
\text { woodland-subtropical } \\
\text { thornscrub }\end{array}$ \\
\hline ? & Rancher (CALG saw skin in Hermosillo) & ? & Nacori Chico, Baviacora & Subtropical thornscrub \\
\hline ? & Hunter (CALG saw skin in Hermosillo) & ? & $?$ & $?$ \\
\hline$?$ & Hunter (CALG saw skin in Hermosillo) & ? & N. of Ures & ? \\
\hline$?$ & Hunter (CALG, saw skin in Hermosillo) & ? & Suaqui Grande & ? \\
\hline
\end{tabular}

${ }^{1}$ Initials refer to authors of the present paper.

\section{Discussion}

The three models of the distribution of ocelots gave similar results, with differences of $10-25 \%$ in area occupied. Carrillo \& Lopez Gonzalez (2002) estimated that ocelots occur at a density of $5.7( \pm 1.9)$ ocelots per $100 \mathrm{~km}^{2}$ in this region, and using this value and the most conservative estimate of ocelot distribution, based on the GARP model, gives an estimate of 2,025 \pm 675 ocelots in Sonora. Local ranchers and cowboys reported to us that the gato galavis (as ocelots are known locally) is relatively common, although during field surveys we rarely located ocelot tracks in comparison with bobcat Lynx rufus sign (C. A. López González, unpub. 
Table 2 Summary of habitat associations for the 36 records of ocelots (see Table 1).

\begin{tabular}{lc}
\hline Biotic community & $\begin{array}{c}\text { Number of } \\
\text { records (\%) }\end{array}$ \\
\hline Subtropical thornscrub & $13(36.1)$ \\
Tropical deciduous forest & $10(27.8)$ \\
Temperate oak woodland & $4(11.1)$ \\
Temperate oak woodland-subtropical & $3(8.3)$ \\
$\quad$ thornscrub or Temperate oak & \\
$\quad$ woodland-tropical deciduous forest & \\
Tropical thornscrub & $1(2.8)$ \\
Desert thornscrub & $1(2.8)$ \\
Pine-oak forest & $1(2.8)$ \\
Data unavailable & $3(8.3)$ \\
\hline
\end{tabular}

data). Ocelot tracks can be distinguished because they tend to be rounder and relatively larger than those of bobcats, and the more elongated toes of the bobcat leave an imprint that is recognizably different from that of the ocelot.

Ocelots are associated largely with the mountainous Sierra region of eastern Sonora. Records closer to the Sonoran desert biome were mainly associated with riparian areas, where the shrub cover is relatively thicker than the surrounding areas. The transformation of desert grassland by the invasion of mesquite Prosopis spp. or other shrubs may actually benefit the ocelots by artificially creating a structurally closed habitat that is preferred by this species (Tewes, 1986; Laack, 1991). A few ocelots in Sonora were recorded in oak woodlands, but all of these records were males. Historically, ocelots occurred in oak/juniper communities of central Texas (Bailey, 1905), but unfortunately they were extirpated there before anybody could describe their natural history in this habitat. Today the ocelot occurs in other, subtropical, habitats of eastern and central Texas (Navarro et al., 1993). The thornscrub in which ocelots mostly occur in Sonora is comparable in structure to the tropical deciduous forest of the coast of Jalisco, Mexico, where López González et al. (2000) found radio-collared ocelots to be preferably selecting pristine tropical deciduous forest and mature secondary growth. Given the paucity of records for southern areas of the US State of Arizona, which borders Sonora, it is unlikely that ocelots were ever native there. There are conflicting opinions regarding the historical distribution of both ocelots and jaguar in this region (Brown \& López González, 2000). In this context Laack (1992) noted that sightings, without documentation, do not provide conclusive evidence of a population of ocelots.

Competition with bobcats may be a factor limiting the number of ocelots able to reach more northerly latitudes, whereas in more southerly, tropical environ- ments ocelots may be limiting the presence of bobcats (López González et al., 1998). In Texas, ocelots and bobcats take the same prey species, and in similar proportions (Tewes et al., 1997). If bobcats are more numerous and feeding on the same prey species as ocelots, any collapse in prey populations would reduce the survival of ocelots because they invest more resources to raise a litter than do bobcats (Emmons, 1988; Sunquist, 1992).

Although ocelots in Sonora are protected in the Sierra Alamos-Rio Cuchujaqui Reserve, in the south of the State, our data indicates that they still occur elsewhere. Our distributional analysis could help identify areas that would, if protected, help to maintain the connectivity of tropical habitats suitable for the ocelot. In this context, natural resource managers will need to give special consideration to the short dispersal distances that characterize ocelots. Although there is no information on this in Sonora, dispersal distances of ocelots elsewhere in Mexico and in Argentina are typically 5-25 km (Caso, 1994; Crawshaw, 1995; López González et al., 2000). Large unpopulated tracts of land remain in the central portion of the State of Sonora, making it one of the few areas in which ocelots may persist in substantial viable populations in its northern range. As noted for other threatened species, the most distant portions of species' distributions have been the last refuge for their survival (Channell \& Lomolino, 2000), and this may also be the case for the future of the ocelot in North America.

\section{Acknowledgements}

Partial funding was provided by the Chase Manhattan Foundation, Denver Zoological Foundation, Idea Wild, Inc., Lincoln Zoo Neotropical Fund, Lyn Chase Wildlife Foundation, Malpai Borderlands Group, Phoenix Zoo, Turner Foundation, and the Wildlife Conservation Society. Lighthawk, Inc., provided flight time for an aerial habitat survey. Arizona State University and the Northern Rockies Conservation Cooperative administered funding. We would also like to thank the many individuals that provided logistic support for the study, and in particular our Sonoran informants who were so cheerful and cooperative in responding to our many outrageous questions. This investigation was carried out under research permit SEMARNAP No. DOO.02.-4157.

\section{References}

Bader, M. (2000) Distribution of grizzly bears in the U.S. Northern Rockies. Northwest Science, 74, 325-334. 
Bailey, V. (1905) Biological survey of Texas. North American Fauna, 25. Department of Agriculture, United States.

Brown, D.E. (1985) Tigrillo: southwest mystery cat. Arizona Hunter, April, 28-29.

Brown, D.E. (1989) The ocelot. Audubon Wildlife Report, 1989/1990, 421-433.

Brown, D.E. \& López González, C.A. (2000) Notes on the occurrences of jaguars (Panthera onca) in Arizona and New Mexico. Southwestern Naturalist, 45, 537-542.

Brown, D.E., Reichenbacher, F. \& Franson, S.E. (1998) A Classification of North American Biotic Communities. University of Utah Press, Salt Lake City, USA.

Burt, W.H. (1938) Faunal relationships and geographic distribution of mammals in Sonora, Mexico. Miscellaneous Publications, Museum of Zoology University of Michigan, 39, 1-77.

Burt, W.H. (1961) A fauna from an Indian site near Redington, Arizona. Journal of Mammalogy, 42, 115-116.

Caire, W. (1997) Annotated checklist of the recent land mammals of Sonora, Mexico. In Life Among the Muses: Papers in Honor of James S. Findley (eds T.L. Yates, W.L. Gannon \& D.E. Wilson), pp. 69-80. Special publication of the Museum of Southwestern Biology no. 3. Albuquerque, New Mexico, USA.

Carrillo, S. \& Lopez Gonzalez, C.A. (2002) Distribution, ecology and conservation of jaguars in Sonara, Mexico. Final Report presented to National Fish and Wildlife Foundation.

Caso, A. (1994) Home range and habitat use of three neotropical carnivores in northeast Mexico. MSc thesis, Texas A\&M University, Kingsville, USA.

Channell, R. \& Lomolino, M.V. (2000) Dynamic biogeography and conservation of endangered species. Nature, 403, 84-86.

CONABIO (1999) Uso de Suelo y Vegetacion agrupado en "Uso de Suelo y Vegetacion de INEGI (1973)". Scale 1:250,000. Available from http:/ / www.conabio.gob.mx [accessed 29 April 2003].

Crawshaw, P.G. (1995) Comparative ecology of ocelot (Felis pardalis) and jaguar (Panthera onca) in a protected subtropical forest in Brazil and Argentina. PhD thesis, University of Florida, USA.

DekstopGarp (2003) DesktopGarp. Http:/ /www.lifemapper.org/ desktopgarp [accessed 29 April 2003].

Emmons, L.H. (1988) A field study of ocelots (Felis pardalis) in Peru. Revue d'Ecologie (Terre et Vie), 43, 133-157.

Endangered Species Program (2003) The Endangered Species Program, US Fish \& Wildlife Service. Http:/ / endangered.fws.gov [accessed 29 April 2003].

Favre, D.S. (1989) International Trade in Endangered Species: A Guide to CITES. Kluwer Academic Publishers, Dordrecht, Netherlands.

Gallo, J.P. (1996). Distribution of the neotropical river otter (Lutra longicaudis annectens Major 1897) in the Rio Yaqui, Sonora, Mexico. IUCN Otter Specialist Bulletin, 13, 27-31.

Goldman, E.A. (1943) The races of the ocelot and margay in Middle America. Journal of Mammalogy, 24, 372-385.

INEGI (1973) Cartas topográficas Estado de Sonora, Escala 1:250,000. INEGI. Aguascalientes, Mexico.

IUCN (2002) 2002 IUCN Red List of Threatened Species. IUCN, Gland, Switzerland [http:/ / www.redlist.org, accessed 2 June 2002].
Laack, L. (1991) Ecology of the ocelot (Felis pardalis) in South Texas. MSc thesis, Texas A\&M University, College Station, USA.

Laack, L. (1992) Observations on Potential Ocelot Habitat in Southeastern Arizona. Unpublished report, Laguna Atascosa National Wildlife Refuge, Texas, USA.

Leopold, A.S. (1959) Wildlife of Mexico, the Game Birds and Mammals. University of California Press, Berkeley and Los Angeles, California, USA.

López González, C.A. (1999). Implicaciones para la conservacion y el manejo de pumas (Puma concolor) utilizando como modelo una poblacion sujeta a caceria deportiva. PhD thesis, Universidad Nacional Autónoma de México, Mexico.

López-González, C.A. \& Brown, D.E. (2002) Distribution and current status of jaguars (Panthera onca) in Northwestern Mexico. In Jaguars in the New Milennium: Status, and Conservation Priorities (eds R.A. Medellin, C. Chetkiewicz, A. Rabinowitz, K.H. Redford, J.G. Robinson, E. Sanderson \& A. Taber). Fondo de Cultura Economica, Universidad Nacional Autónoma de México and Wildlife Conservation Society, Mexico.

López González, C.A., Gonzalez Romero, A. \& Laundre, J.W. (1998) Range extension of the bobcat (Lynx rufus) in Jalisco, Mexico. The Southwestern Naturalist, 43, 103-105.

López González, C.A., González Romero, A., Hidalgo Mihart, M.G. \& Cantu Salazar, L. (2000) The Conservation and Management of the Carnivore Community of a Tropical Dry Forest of Western Mexico. Unpublished report, Earthwatch Inc., USA.

McCurdy, R. (1981) Life of the Greatest Guide: Hound Stories and Others of Dale Lee. Blue River Graphics, Phoenix, USA.

Murray, J.L. \& Gardner, G.L. (1997) Leopardus pardalis. Mammalian Species, 548, 1-10.

Navarro, L.D., Rappole, J.H. \& Tewes, M.E. (1993) Distribution of the endangered ocelot (Felis pardalis) in Texas and Northeastern Mexico. In Avances en el Estudio de los Mamiferos de Mexico (eds R.A. Medellin \& G. Ceballos), pp. 157-169. Asociacion Mexicana de Mastozoologia Asociacion Civil, Mexico.

Nowell, K. \& Jackson, P. (1996) Wild Cats: Status, Survey and Conservation Action Plan. IUCN/SSC Cat Specialist Group, IUCN, Gland, Switzerland and Cambridge, UK.

Oliveira, T.G. (1994) Neotropical Cats: Ecology and Conservation. EDUFMA, San Luis, Brazil.

Reichenbacher, F., Franson, S.E. \& Brown, D.E. (1998) North American Biotic Communities (Map:1:10,000,000). University of Utah Press, Salt Lake City, USA.

Rzedowski, J. (1979) Vegetación de Mexico. Limusa, Mexico. SEDESOL (1994) Norma Oficial Mexicana 059. Diario Oficial de la Federacion 16 de Mayo de 1994.

Stockwell, D.R.B. \& Noble, I.R. (1991) Induction of sets of rules from animal distribution data: a robust and informative method of data analysis. Mathematics $\mathcal{E}$ Computers in Simulation, 32, 249-254.

Stockwell, D.R.B. \& Peters, D. (1999) The GARP modelling system: problems and solutions to automated spatial prediction. International Journal of Geographic Information Science, 13, 143-158. 
Sunquist, M.E. (1992) The ecology of the ocelot: the importance of incorporating life history traits into conservation plans. In Felinos de Venezuela: Biologia, Ecologia y Conservacion, pp. 117-128. FUDECI, Caracas, Venezuela.

Tewes, M.E. (1986) Ecological and behavioral correlates of ocelot spatial patterns. PhD thesis, University of Idaho, Moscow, USA.

Tewes, M.E., Young, J. \& Laack, L. (1997) Food habits of co-occurring ocelots and bobcats. In Current research of the Caesar-Kleberg Wildlife Institute 1996-1997, pp. 37. Texas A\&M University, College Station, USA.

USFWS (1999) Endangered and Threatened Wildlife and Plants. U.S. Fish and Wildlife Service, Washington, DC, USA

Worton, B.J. (1989) Kernel methods for estimating the utilization distribution in home-range studies. Ecology, 70, 164-168.

\section{Biographical sketches}

Dr. Carlos A. López González is a Research Associate of the Denver Zoological Foundation and the Northern Rockies Conservation Cooperative. He has been carrying out research on carnivore conservation since 1991.

David E. Brown is interested in biological processes in the south-western United States and north-western Mexico, and has more than 20 years of research experience in this region of the Americas.

Dr. Juan Pablo Gallo Reynoso is principally interested in the conservation of marine mammals and otters. 